\title{
"The pitch itself was no man's land": Siege, Željezničar Sarajevo Football Club and the Grbavica Stadium
}

\author{
Richard Mills* \\ University of East Anglia, Norwich, United Kingdom
}

\begin{abstract}
Inspired by microhistory, this essay explores the wartime plight of a football stadium and the multi-ethnic club that called it home as a means of understanding Bosnia and Hercegovina's descent into conflict, the siege of Sarajevo and the impact upon civilians. Like the suburb of the same name, Grbavica became part of the frontline during the siege. Deprived of its home, FK Željezničar continued to function, while players, staff and supporters longed for a return to the shattered ground. At a local level, the organisation offers a means of visualising the development of the Grbavica suburb, from its socialist foundations to its post-Dayton reintegration. In this way, the life of the stadium and those who frequent it map onto the history of Yugoslavia, its dissolution and the independent republic that emerged in its wake. Moreover, the wartime partition of the stadium, the club and its supporters' group - all of which were claimed by actors on both sides of the frontline - were representative of political developments in a state where the ethnic balance was forcibly reengineered. This reconstruction of Grbavica's war harnesses original photographic evidence, oral history, maps, contemporary journalism, and the transcripts of the Hague Tribunal.
\end{abstract}

Keywords: Football; War; Bosnia and Hercegovina; Yugoslavia; Sarajevo

\section{Introduction}

In October 1991 the remains of Yugoslavia's national team travelled to the Bosnian capital of Sarajevo for a friendly match against Željezničar Football Club of the First Federal League. The match was held to mark the seventieth anniversary of Željezničar, with former club legend Ivica Osim bringing the national team, under his stewardship, to the city of his birth for the occasion. By this time Croatia and Slovenia had officially seceded from Yugoslavia, as the European Community's three month moratorium on independence expired. However, war still raged throughout much of Croatia's territory, and there were serious concerns that the fighting might spread to the neighbouring ethnic "kaleidoscope" that was the Yugoslav republic of Bosnia and Hercegovina (Malcolm 2002, 235). Misha Glenny has noted that those people who were in the best position to understand the likely outcomes of Yugoslavia's disintegration feared for the fate of this central republic the most, with foreign

\footnotetext{
*Email: R.Mills@uea.ac.uk
} 
recognition of Slovenia and Croatia pushing it "into the abyss" (Glenny 1996, 143). Foreboding for Bosnia's future was made more acute when its citizens voted largely along ethnic lines in the republic's first democratic elections in 1990. It was in these circumstances that the aforementioned friendly match took place. A Belgrade journalist eagerly reported that in "the most dismal period of the Balkans' recent history, when the Yugoslav state is being torn apart ... a sobering breeze of reconciliation has blown from the soccer fields to the bloody fronts nearby" (Simeunović 1991). Three doves of peace were released by the players prior to kickoff (M. B. 1991). Twenty thousand Sarajevans filled Željezničar's Grbavica Stadium for a fixture which had been "awaited with much trepidation and anxiety" in the "boiling 'Bosnian stewpot"":

...members of the Moslem, Serbian and Croatian peoples, above all young people, ..., cheered Yugoslavia, sang to peace, and this athletic ode was topped by individuals who climbed down to the field carrying flags during the game. (Simeunović 1991)

The climax of this upbeat article, written from the perspective of a Belgrade desperate to prevent the secession of Bosnia, triumphantly stated:

Soccer and sports have again beaten the madmen. In Grbavica, in Sarajevo in which many peoples live, it was again proven that Yugoslavia still resides in Bosnia in these times of wartime atrocities... (Simeunović 1991)

Less than six months later armed conflict would break out across Bosnia and Hercegovina, multi-ethnic Sarajevo would be besieged in pursuit of mono-ethnic goals, and the Grbavica Stadium would itself become a frontline for the duration of the conflict.

Yugoslav football, like every other activity, was heavily affected by the wars of the 1990s. Recently, a growing body of research has been dedicated to the history of the game during this period (see, e.g. Hughson and Skillen 2014; Brentin, Galijaš, and Paić 2014; Zec and Paunović 2014; Mills 2010, 2012). The interaction between football and ethnic politics has also been explored in the context of post-war Bosnia and Hercegovina (see, e.g. Cooley and Mujanović 2014; Sterchele 2013; Özkan 2013, 2014). Conducted in the spirit of microhistory, this essay seeks to add to our understanding of the interplay between sport and conflict by "asking large questions in small places" (Joyner 1999, 1; Ginzburg 1993. See also, Eriksen 2001). Specifically: What can the plight of a single football stadium, and the multi-ethnic 
football club that called it home, tell us about Bosnia and Hercegovina's descent into conflict, the nature of Sarajevo's siege and the impact of war upon multi-ethnic organisations? In order to grasp the ruptures of the 1990s, it will also be necessary to explore socialist-era developments. This was a period when the club and its stadium evolved and flourished concurrently with the urban area that envelops them. Alongside a photographic survey of the stadium and the surrounding area, the essay draws upon a wide range of source material, including interviews with individuals who actively supported the club throughout the period in question, newspaper and magazine articles, contemporary images and maps, as well as a number of rich monographs dedicated to the history of Željezničar and the Grbavica suburb (Anđelić 1982; Hadžialić 2007; Kajan 1999, 2007). The transcripts of the International Criminal Tribunal for the former Yugoslavia have proved to be a valuable resource for understanding the nature of the fighting in this part of the city.

In his study of British football grounds during World War One, Brandon Luedtke describes the ways in which these facilities became "inherently, a landscape of war" $(2012,98)$. The venues in question were harnessed for recruitment, as drill grounds for the military and for grazing livestock. In this way, Luedtke investigates "the reinventions" of these sporting facilities at a time of extensive mobilisation (2012, 99-104). In addition to this repurposing on the home front, he also explains that soldiers were eager to recreate these familiar landscapes on the battlefield. This took place both as a symbolic gesture - with footballs being kicked into no man's land to mark the start of an offensive - and materially - with makeshift football pitches being carved out behind the lines by war weary troops (Luedtke 2012, 107112). During the Second World War a number of British grounds were damaged by aerial bombing, while others were harnessed as air raid shelters and ammunition stores (Lanfranchi and Taylor 1995, 194). In more recent conflicts stadiums have served as refugee camps, detention facilities and execution sites (Read and Wyndham 2008, 82-84; Arich-Gerz 2010). While, on the Western Front, soldiers fashioned "magnificently scarred landscapes of war into recreational grounds", we will see that at Grbavica this process operated in reverse (Luedtke 2012, 108). Nevertheless, this did not prevent the stadium from becoming highly symbolic for the city's residents. Many of them yearned for a return to the kind of normality encapsulated by a league match at a ground which the siege placed tantalisingly out of reach. 


\section{FK Željezničar, Grbavica Stadium and the Maniacs}

The Željezničar [Railway Worker] Football Club, or Željo - as it is affectionately referred to - was founded in 1921. As the name suggests, the club was formed by young employees of the Main Railroad Workshop and, unlike most other teams in the city, Željo did not represent a specific confessional group (Anđelić 1982, 10-13 and 61-62). A modest organisation during the interwar years, Željo competed in local Sarajevo competitions. As a workers' club, it was always associated with radical politics, something that brought it to the attention of the authorities of the short-lived Kingdom of Yugoslavia, who rightly suspected that it harboured illegal communist activists (Anđelić 1982, 62-64). When Yugoslavia was forcibly erased from the map following the Axis invasion of 1941, Sarajevo became part of the fascist puppet Independent State of Croatia. Unwilling to accept the new regime, Željo - with its politically suspect base of skilled workers - ceased to exist. Many club members embraced the communist partisans, making a significant contribution to the National Liberation Struggle. Those footballers and officials who fell in the process were subsequently venerated when peace returned to the city (Anđelić 1982, 64-67). This proud wartime record undoubtedly laid the groundwork for Željo's bright future in socialist Yugoslavia. After liberation, it was among the select few teams which were allowed to resume sporting activities. Those tainted by collaboration or narrow confessional pasts were forcibly disbanded by the new socialist authorities (Mills 2013a, 47-52).

At the beginning of the socialist era Željo did not have a ground of its own. As a result, in the immediate post-war period the team played home matches at the stadium of the disgraced Slavija Sarajevo. ${ }^{1}$ This ground - located on the site of the iconic Holiday Inn, famous for its association with the 1984 Olympics and the subsequent siege (Morrison 2013) - was swiftly renamed the "6 April" Stadium to mark the day of the city's liberation. Željo played there until 1950, when the facility was demolished to make way for a new boulevard [Fig. 1]. While there, Željo rose to the top of the Yugoslav game, qualifying for the very first Federal League of 1946-47. However, the club performed poorly and was relegated to a lower level of competition. After the demolition of the old Slavija ground, Željo temporarily moved to another stadium in the centre of the city, as construction began on the club's new Grbavica Stadium. The latter was located on the edge of the emerging suburb of the 
same name, with the hills that encircle Sarajevo rising sharply behind it (Kajan 2007, 205-210).

Between 1949 and 1953, hundreds participated in the development of the new ground. Like so many stadiums across socialist Yugoslavia, it was built through voluntary actions. In this case, brigades of railway workers were joined by the People's Front and youth organisations, as well as enthusiastic locals. Miladin Draškić, who served as president of the overseeing committee for the new stadium, has described the project in some detail (1988, 591-592):

Bearing in mind that at that time the association did not have the means to pay for a bulldozer, or even its own tools, the worker-volunteers brought their own picks, shovels, old bowls, wash-basins and saucepans with them, because they did not even have wheelbarrows.

The volunteers worked evenings and Sundays, devoting thousands of hours to levelling the pitch and laying the terraces. Railway workers from all over Bosnia and Hercegovina performed such tasks as transporting stone to the new ground. The city authorities assisted in a number of ways, including a decision to donate the wooden stand from the "6 April" Stadium free of charge. This impressive structure was reassembled and roofed at Grbavica, giving the new ground 2,500 covered seats (Draškić 1988, 594). It was an iconic building which was still in place when war broke out in 1992 [Figs 1 and 2].

\section{Figure 1 and Figure 2 here}

Željo kicked off in their new surroundings in September 1953. The first match, a victory over Šibenik in the Second Federal League, was watched by a packed crowd of 10,000 (Anđelić 1982, 107; Kajan 2007, 212).

In his unapologetically nostalgic look back at the Grbavica suburb of the 1950s and 1960s, Dževad Kajan describes the football ground as a magical place (Kajan 2007, 213-214). In its first decades a narrow-gauge railway line passed behind the southern wall of the stadium and engine drivers would regularly slow down to greet players and spectators with a toot of the locomotive's whistle. In these early years of the ground's history, the surrounding districts of Grbavica and Hrasno were sparsely populated areas on the periphery of Sarajevo. They were characterised by "small private cottages, girdled by wooden fences, and extensive open meadows" (Kajan 2007, 216). During this period, many Željo supporters travelled back to the 
city centre on double-decker Leyland buses which connected these outlying suburbs. Kajan's description of the area is corroborated by contemporary photographs (See Fig. 2 and Anđelić 1982, 239-244). The rapid urban development of the suburb and the stadium that bore its name occurred simultaneously, as part of socialist Sarajevo's inexorable expansion. As the stadium closed for renovation in 1968, the urbanisation of the surrounding area also accelerated. By the mid-1970s the quaint cottages and meadows had been replaced by wide boulevards and high-rise accommodation. Trolleybuses ran down the asphalt Dinarska Street [now Zvornička], which passes in front of the stadium (Kajan 2007, 216). In the decade that followed, the football ground was enlarged with the addition of the modern concrete North Stand, which did not look out of place alongside the colossal apartment blocks of the adjacent streets.

As the team settled into their new surroundings, experiencing the ups and downs of competitive football with their growing fanbase, Kajan notes that the stadium gradually "became a symbol of Željo which simply fused with the club and its loyal supporters" $(1999,28)$. This is a prime example of a phenomenon that John Bale discusses in the context of British football, using Yi-Fu Tuan's concept of "topophilia". Regular visits and experiences at the grounds of beloved clubs cultivate a deep emotional attachment in supporters, coupling sentiment with place $(1993,64-$ 69). In this way, for some supporters, players and officials "the ground for which they have developed a profound sense of topophilia" is viewed as a kind of "home" (Bale 1993, 70). The simultaneous development of the Grbavica Stadium and surrounding residential suburbs can only have served to strengthen these bonds.

Like the rest of the city, the suburb of Grbavica was multi-ethnic and Željo reflected this ethnic diversity. Players and supporters came from all confessional backgrounds. As Ivana Maček notes (2009, 124), socialist-era Sarajevo was a predominantly secular society, within which "ethnoreligious background was not a strong factor by which people were differentiated, especially in public and social life". Many of the great Željo players grew up in close proximity to the Grbavica and the club built its success upon local talent. The pinnacle of its achievements came in 1972, when a multi-ethnic Željo won the Yugoslav First Federal League and went on to represent the state in the European Cup. The names of the championship winning players, many of whom grew up in Grbavica, demonstrate the ethnic diversity of both Željo and the city of Sarajevo: 
1971-72 squad: Slobodan Janjuš, Dragan Kojović, Velija Bećirspahić, Blagoje Bratić, Josip Katalinski, Enver Hadžiabdić, Branimir Jelušić, Božo Janković, Josip Bukal, Edin Sprečo, Avdija Deraković, Slobodan Kojović, Fahrija Hrvat, Džemaludin Šerbo, Nusret Kadrić, Hajrudin Saračević, Miloš Radović, Željko Rodič.

1971-72 coaches: Milan Ribar, Sulejman Kulović, Fadil Požegija (Anđelić 1982, 166-170).

Ironically, this triumphant campaign was not played out at the Grbavica Stadium, as it occurred during the period of its renovation (1968-1976). While this was taking place the club played home matches at the Koševo Stadium, the ground of city rivals FK Sarajevo, on the other side of the city (Kajan 1999, 26). Following the success of 1972, Željo regularly competed in the First Federal League, rarely dropping out of this elite level of competition. Moreover, the club represented Yugoslavia in the UEFA Cup during the 1980s, reaching the semi-finals with Ivica Osim as coach in 1985 (Hadžialić 2007, 142-144). At the time of Yugoslavia's demise, the club was competing at the highest federal level.

While Željo had been well supported since its first match at the Grbavica, in 1987 an autonomous supporters' group, “The Maniacs”, was founded. Largely following the trends and fashions of organised young supporters across Western Europe and elsewhere in Yugoslavia, this group nevertheless explicitly adopted a multi-ethnic outlook at a time when comparable groups were indulging in nationalist and ethnocentric politics on a regular basis [Fig. 3].

Figure 3 here

Such an outlook is partially explained by the ethnic composition of Sarajevo. In 1991 the 527,000 inhabitants were $49 \%$ Muslim, 30\% Serb, 7\% Croat and 14\% other. The latter were predominantly self-declared Yugoslavs, many of whom were the children of mixed marriages (Sell 2000, 181). Although the percentage of such marriages in the city is contested - Tom Gjelten $(1996,10)$ gives a figure of $34.1 \%$ for 1991 - it was among the highest in socialist Yugoslavia. An overarching Yugoslav identity was also embraced by many of those who self-identified with a particular ethnic group. In an interview with individuals who had been members of the Maniacs from the earliest days, it was explained that the group:

... consisted of different religions, different nations - and they did not differentiate between which ethnicity people came from, or what type of praying people did. (Interview 2008) 
However, as the political situation in Yugoslavia deteriorated it became ever harder for the Maniacs to avoid nationalist politics. Its leaders made this clear in a Ćao tifo interview in 1991 (“"Manijaci' protiv”):

Everyone is pushing their own national interests, while for a long time we put up with all that and felt like Yugoslavs. To us 'The Maniacs' consists of all nations so it was normal that we felt like this. But whoever comes to the Grbavica provokes us. For a long time we did not respond to such provocations, but we had also had enough and since then we started to support the SDA [Stranka demokratske akcije, Party of Democratic Action - the leading Muslim party] ...

This statement was made less than a year before war began in Bosnia. Ironically, it was not only questions of political allegiance which troubled the Željo camp during the 1991-92 season. Player strikes over unpaid wages meant that youth team footballers were fielded in the First Federal League, while a lengthy dispute between the club's administration and the Maniacs resulted in the latter boycotting the stadium (Hadžialić 2007, 54; “"Manjaci’ protiv” 1991). Yet, all of these problems would pall into insignificance with the outbreak of war.

On 15 October 1991 the Bosnian Serb leader Radovan Karadžić warned his Muslim counterparts not to attempt to separate Bosnia from Yugoslavia:

This is the road that you want to lead Bosnia and Hercegovina down, the same highway of hell and suffering that Slovenia and Croatia departed on. Do not think that you will not drive Bosnia and Hercegovina to hell, and perhaps the Muslims to extinction. Because the Muslims will not be able to defend themselves if it comes to war here! ... How will you prevent everyone from killing each other in Bosnia and Hercegovina? ("Transkript govora" 1991, 3)

This was a warning that would haunt the republic's Muslim community in the years to come. The referendum on independence which followed on 29 February and 1 March 1992 - and was ominously boycotted by much of the Serb population - returned an almost unanimous vote in favour of an independent Bosnia and Hercegovina. An earlier unofficial plebiscite for Bosnia's Serbs produced the polar opposite outcome and virtually guaranteed that war was immanent in the process. Immediately after the independence referendum armed masked men from the leading Bosnian Serb and Muslim parties erected barricades at strategic points across Sarajevo. Although politicians were able to reach an agreement and the barricades were swiftly removed, the situation remained tense throughout March (Donia 2009, 277-279). 
As was the case elsewhere in Yugoslavia, political unrest was reflected in football. Indeed, leading Belgrade publications speculated upon the plight of the game in Bosnia and Hercegovina. Sportski žurnal noted that football "remained on the barricades", while its journalists - in keeping with Serb nationalist plans to carve out an ethnically homogenous territory - even staked a claim for Željo as a Serbian club. This was supposedly the case because the Grbavica Stadium was located in the Novo Sarajevo municipality, "where Serb inhabitants are the most numerous" (Bjelogrlić 1992a). However, even if one accepted the concept of allocating districts and clubs on the basis of ethnic majorities, this claim of Serb predominance is not backed up by 1991 statistics, which show a roughly equal number of Serbs (34.6\%) and Muslims $(35.7 \%)$ in the municipality (Donia 2009, 266). ${ }^{2}$ Moreover, it should also be stressed that Željo's fanbase stretched far beyond the administrative unit in question.

\section{War comes to Grbavica}

Unlike the relatively peaceful political "disassociation" of Croat and Slovene clubs, the abrupt exodus of Bosnian teams from the First Federal League came as a result of direct military conflict. The war began in earnest one week before an independent Bosnia and Hercegovina was due to be recognised by the international community on 6 April (Glenny 1996, 167-171; Donia 2009, 277-279). With large amounts of weaponry having been transferred to Bosnian Serbs by the Yugoslav People's Army in the first months of 1992, the north-eastern town of Bijeljina was attacked by Serb paramilitaries at the beginning of April. An extensive ethnic cleansing campaign was underway (Donia 2009, 281-282; Silber and Little 1996, 222-230; Glenny 166-178). Over the weekend of the $4^{\text {th }}$ and $5^{\text {th }}$ the war descended upon Sarajevo itself, as Bosnian Serbs accelerated efforts to carve out their own ethnically homogenous polity in resistance to Bosnia's imminent secession from Yugoslavia.

On Sunday 5 April Željo were scheduled to play a home game at their Grbavica Stadium against Rad [Work] Belgrade in the Yugoslav First Federal League. As it transpired, this was to be the last sporting use of the stadium for four years. Unbeknownst to the teams and supporters that arrived for the match, Serb forces planned to seize the city's Vraca Police Academy - and its large weapons cache - on the day of the game (Lučić 1992; Silber and Little 1996, 226). Sarajevo's Police Academy was strategically important because it overlooked the suburb of Grbavica and the national Assembly Building (Donia 2009, 283). The facility is situated just up 
the hill from the football ground, with the two locations only separated by a small wooded area, some houses and a road [Map 1]. ${ }^{3}$

Map 1 here

A number of reports in the following day's Sportski žurnal covered the events as they unfolded. The correspondent reported that the players were accommodated in the "Evropa" and "Bristol" hotels, and that football association delegates, match officials and club staff debated all morning whether or not to play the match. According to this Belgrade publication, the game was in doubt because:

Last night genuine street battles were underway in several parts of the city ... and even a number of police stations were attacked, including the one in the district of Novo Sarajevo to which the Grbavica Stadium belongs. On that occasion one policeman was killed and because of this the station will not hear of patrolling the stadium for the match, as manpower is committed to the execution of other, much more important tasks. (Bjelogrlić 1992b)

Željo coach Nenad Starovlah told the reporter that his footballers had been in quarantine at the Hotel "Bristol" - subsequently ruined during the siege [Fig. 4] since the night before:

Nobody is thinking about the match and the whole night none of the players got a wink of sleep. The shooting reverberated incessantly, everyone is afraid and worried. Who needs such a sport as football? (Bjelogrlić 1992b)

Figure 4 here

Less than two hours before kick-off the visiting team were engaging in their habitual preparations, assuming that the match would go ahead. However, one of the linesmen - Mevludin Omerhodžić from Brčko in the north-east of the republic - did not arrive in the city on the morning of the game (Bjelogrlic 1992b). Without a police presence and a full complement of officials, Željo's encounter with Rad was cast further into doubt. In addition, barricades were once again in place across the municipality's streets. Despite these developments, Željko - a member of the Maniacs supporters' group - recalls (Interview 2008) that around fifteen hundred spectators gathered at the stadium prior to kick-off: 
The last match, I can remember, was against Rad Belgrade and I was on the North Stand and - of course - the match was abandoned almost in the beginning ... because of the shooting from the hills, and the war started. ... at that time the war in Croatia had already started, but of course we did not believe that it would happen in Bosnia so we went to the match. But when shooting started in Grbavica we realised - OK, that is game over.

After the shooting began in the hills above, Željko remembers that "the match was stopped and the players simply left the pitch and we split out of the stadium..." (Interview 2008).

These recollections are partially corroborated by the aforementioned report in Sportski žurnal (Bjelogrlić 1992b), though it appears that the match did not actually kick-off prior to its abandonment just before $3 \mathrm{pm}$. Having explained that the footballers had arrived at the stadium, the dispatch states:

Just at the time when the conversation about whether to play the match was being conducted, directly above the Grbavica Stadium a genuine war was being fought. At that time machine-gun bursts flew from every direction. It was clear to everyone that today at the Grbavica only a competition in 'applied rifle shooting' could take place, and not football.

The correspondent who filed this report explained that he had only succeeded in getting within one hundred metres of the ground, with it being too dangerous to go any further. He evidently feared for the safety of the players inside (Bjelogrlić 1992b). The English-language edition of Politika covered events from the perspective of the Rad Belgrade club (Simeunović 1992), which went to Sarajevo despite the fact that Bosnia "was on the brink of a civil war":

At Grbavica stadium, they were greeted by cross-fire from armed national groups, and together with their football mates of Željezničar, they sought shelter in the basements of the stadium. Luckily they were later able to escape from the shelter and to reach the blocked Sarajevo airport from which they took off in a special small plane.

The airport was seized by Serb and Yugoslav People's Army forces later that night (Silber and Little 1996, 228). ${ }^{4}$ Some Serbian Željo players and their families would also flee via the airport in the coming days (Šećerov 1992a). The shooting which both of these sources refer to originated from the joint Bosnian Serb and Yugoslav People's Army attack on the Vraca Police Academy just above the stadium. The assault on this facility, defended by lightly armed government forces, unfolded over the course of the afternoon. At 4pm the academy's director appealed for assistance, 
but he was powerless to prevent the seizure of the complex and the taking of hundreds of prisoners (Donia 2009, 284). This clash "became the first point of conflict in Sarajevo" (Silber and Little 1996, 226).

The same afternoon also witnessed a peace procession through the city by tens of thousands of citizens. It ended tragically on the Vrbanja Bridge, where protesters were targeted with grenades and automatic rifle fire. A female student, Suada Dilberović, was killed during this incident. Such peaceful gatherings came to nothing, as protestors were gunned down outside the Holiday Inn on the following day. By Monday evening Sarajevo was completely surrounded and blockaded by Bosnian Serb forces. What transpired to be a gruelling four year siege had begun (Judah 2000, 211). For Željezničar, Sunday the $5^{\text {th }}$ "was the day after which nothing would ever be the same" (Hadžialić 2007, 55).

The abandoned Grbavica match was by no means the only game affected by the beginning of the Bosnian War over this April weekend. Many clubs from both the first and second federal leagues experienced problems where a Bosnian team was involved, with a number of matches being cancelled:

The disruption of transport on the territory of this republic by countless road blocks from which justice is carried out by masked members of the Moslem, Serb or Croat nationalities, also stopped the players. (Simeunović 1992)

Despite the declaration of independence and the rapidly deteriorating political situation, leading Bosnian clubs were initially keen to complete the season. As Serb forces seized control of large swathes of Bosnia and Hercegovina, Željo's city rivals FK Sarajevo travelled to Belgrade to play against Crvena zvezda [Red Star]. The match - played on the same day as the ill-fated Grbavica encounter - passed peacefully, but the visiting squad struggled to return home. Three days after the game, as their city was subjected to intense shelling, these footballers were still reluctant residents at Belgrade's Metropol Hotel. Fellow Sarajevan Ivica Osim paid them a visit, while FK Sarajevo's head coach - perhaps naïvely - still did not rule out a match against Željezničar, scheduled to take place at the Koševo on the following weekend (M. A. 1992). However, the onset of war made it impossible for most of the republic's clubs to continue. ${ }^{5}$ At the end of the season, having played substantially fewer matches than most, Željo officially occupied bottom position in the Yugoslav First Federal League (Hadžialić 2007, 54). In reality, the situation was far worse. 


\section{Grbavica becomes the frontline}

Hamo of Željezničar's Maniacs supporters' group recalls (Interview 2008) that Grbavica became a "battlefield” almost immediately: “...after two days this stadium was the frontline." Unlike the other former Yugoslav republics, organised competitions encompassing the respective territories took over a year to emerge on both sides of the Bosnian frontline (Arnautović 2005, 302-304; Mills 2013, 953). Željezničar's stadium became a shattered and dramatic symbol of this. The division of Sarajevo into ethnically exclusive parts was a key Bosnian Serb war aim, which sought to eradicate common life in the city, undermining the prospects for an independent and unified republic in the process (Donia 2009, 288). The suburb of Grbavica was effectively cleft in two in May 1992, when an early Serb offensive aimed at cutting the city in half at its narrowest point failed (Judah 2000, 212). Silber and Little state $(1996,234)$ that the resultant division became the "basis for a de facto partition of Sarajevo", with a line that "divided naturally cohesive inner-city communities, and separated parents from their children, a wholly artificial and arbitrary military barrier which, overnight, became ... a new frontier between enemy states." The frontline between Serb and Bosnian Government forces cut straight through the Grbavica Stadium [Map 1 and Fig. 5].

Figure 5 here

Sitting in Café Macchiato, which is located at the foot of the Loris Building a colossal socialist-era pink residential block that sits across the road from the stadium - Željko explained that "this building was the furthest point of the Bosnian Army". It was destroyed by Serb forces who occupied the blue apartment block on the opposite side of Milutin Đurašković Street [now Topal Osman-paše], along with all of the buildings behind it (Interview 2008). The frontline ran across the T-junction where this street meets Dinarska and terminates at the Grbavica Stadium. ${ }^{6}$ When walking along this wide tree-lined avenue today, it is only the pockmarked balconies of the Loris and the occasional concrete pillbox that give away its wartime position [Fig. 6].

Figure 6 here

However, Maček's recollections from the spring of 1996 (2009, 109-110), shortly after the fighting had ceased, offer a very different picture: 
The whole building was the front line, and it was amazing that any civilians there survived. Bosnian army ... units became a part of their daily lives, and they developed friendly relations with soldiers who were placed there. The building had been a battlefield. We could walk through it from one end to the other because holes had been blown in the walls that had previously separated staircases and apartments. As I followed a friend who lived there through the building, I became numb from seeing the devastation. Some deserted apartments had been shelled and almost completely burned. In others everything was a mess, but I could see the possessions of the departed owners: saucepans and coffee cups, smashed porcelain, heaps of clothes, old letters and postcards. In was macabre that private belongings were so nakedly exposed.

The floodlights of Grbavica, which draw attention to the ground's location at the end of Đuraškovića and are visible from the unfortunate Loris apartments, also carry the scars of machinegun fire.

The stadium itself was heavily damaged in the fighting, with unconfirmed reports of shelling appearing in the Belgrade press within weeks of the outbreak of war. Its exposed position in a fiercely contested part of town meant that those involved with the club found it difficult to obtain accurate information. Speaking two weeks after the abandoned match against Rad, Željo's technical director and former star player, Josip Katalinski, noted that staff had been unable to reach the stadium in the meantime: "It is a fact that frequent detonations are heard around the stadium, but whether or not some shell has fallen on the pitch nobody knows" (Bjelogrlić 1992d). In the months that followed the condition of Grbavica deteriorated rapidly. Željko recalls:

The West Stand was burnt down entirely, and the North as well - so there was no roof at all - only the concrete remained. So only the things which could not be burnt by fire - so this means the concrete and nothing else. ... You had a pitch with trees growing on it, so that the grass on the pitch was entirely unusable. ... it really looked like Stalingrad. (Interview 2008)

The West Stand went up in flames in May 1992, along with all of the club facilities located behind it (Hadžialić 2007, 55). The inferno that tore through the structure was captured on a shaky home video camera from a high apartment on the Bosnian Government-held side. ${ }^{7}$ A rare link to Željo's pre-Grbavica past, the loss of this iconic structure was a monumental blow. The stand housed hundreds of trophies and other objects of symbolic importance that now survive only in the beautiful photographs of socialist-era club histories (Anđelić 1982, 305-312). 
Željko remembers (Interview 2008) that right up until the mid-2000s it was still possible to see "trenches and a hole for a machine gun of the Serbian Forces" behind the South Terrace. The ground was intermittently occupied by Bosnian Serbs, but "the pitch itself was no mans land. There were no guts on either side to go on to the pitch." These recollections are corroborated by testimony from the Hague Tribunal. One witness, whilst discussing the exact location and width of the front-line in this part of the city, stated: "At some points it was a small distance; at others, it was a large distance. For example, at the Grbavica stadium, it was rather large." When asked how large, the witness replied: "Well, the breadth of a stadium." 8 Another witness, confirming that the front-line ran down Milutin Đurašković Street, stated that the stadium was actually occupied by Serb "Chetniks". 9 The latter is a derogatory term for Serbian nationalists, derived from the disgraced Četnik movement that committed atrocities against Muslims during the Second World War. In a different case, a witness noted: “The Željezničar Football Stadium was a no man's land." ${ }^{10}$ Tall buildings in the occupied suburb of Grbavica served as bases for Bosnian Serb snipers to target the streets of the besieged city (Sell 2000, 179). It certainly appears as though they also utilised the rear of the high concrete North Stand, from which one can see directly down Milutin Đurašković Street [Fig. 7]. ${ }^{11}$

Figure 7 here

Vic Duke and Liz Crolley have carried out research on a very similar situation in Cyprus, where the stadium of Nicosia's Turkish Cypriot club Chetin Kaya was lost to the frontline in 1963. After this the abandoned facility became part of Nicosia's United Nations buffer zone $(1996,79)$. Photographs of this stadium show that the pitch was diagonally intersected by the UN's partition wall (Ankant 2008).

Željo's adjacent training field also witnessed heavy fighting, with one Hague Tribunal witness testifying that "quite a lot of soldiers died during the battle at this auxiliary stadium". ${ }^{12}$ Željko recalls (Interview 2008) that this area had to be cleared of landmines after the war. Around 50,000 Serbs remained under Bosnian Government control in the besieged city for the duration of the conflict (Sell 2000, 182). A number of these were forced by the Bosnian Army to perform the lethal task of trench digging in the vicinity of the stadium. A witness at the Hague testified that he was compelled to dig trenches alongside "fellow Serbs who had stayed in Sarajevo", as well as some Muslims [Bosniaks] who "refused to fight". ${ }^{13}$ Trench digging, carried out by civilian 
defence units, was an extremely dangerous activity. Some Bosnian Government soldiers were allegedly reluctant to provide necessary information about the terrain and associated dangers from Serb positions because most of the diggers were Serbian civilians. As a result, trench diggers "often felt that they were exposed to the fire from both sides" (Maček 2009, 210). According to witness statements, the trenches in question ran from the Loris Building on Milutin Đurašković Street, across the training field and up the hill above the stadium [Map 1 and Fig. 8]. ${ }^{14}$

\section{Figure 8 here}

Deprived of their ground and engulfed by war, Željo's members were not prepared to abandon the game entirely. Indeed, by the middle of July 1992, the work of the overarching Željezničar Sports Association - a multi-sport product of the socialist era - had been resumed and members soon started to discuss the feasibility of holding small-sided football matches in indoor venues (P. T. 1992c, 1992d; "Josip Katalinski” 1992). Games involving teams from across the city were held at the Skenderija sports complex and in serviceable school halls. In this way, Željo and the city's other teams contributed to a rich cultural scene in besieged Sarajevo. In addition to a shortage of suitable pitches, Željo's exile from Grbavica also left the club short of the most basic equipment. In 1994, assistance was forthcoming from a number of Bosnian clubs, including city rivals FK Sarajevo, as Željo attempted to return to competitive football. The French company Intersport donated 180 kits and other necessary items for the club's senior, youth and junior squads. These were presented at a ceremony attended by the French ambassador and the commander of the Sarajevo sector of UNPROFOR [United Nations Protection Force]. On that occasion, club president Mirsad Delimustafić expressed his hope that the latter might assist Željo in its desire to return to its stricken stadium (P. T. 1994b).

Resumption was made all the more difficult by the fact that many of the best players had fled the city. In a process replicated across the former Yugoslavia, the most talented footballers continued their careers elsewhere in Europe (Lanfranchi and Taylor 2001, 136-139). Following the outbreak of hostilities Željo players went on to play for Real Madrid, Benfica and Anderlecht, among other clubs (Hadžialić 2007, 55). Others sought refuge in the leagues of neighbouring republics, or less volatile parts of Bosnia. Belgrade's Sportski žurnal covered this exodus in the first weeks of the war, noting that nine of the club's footballers had left Sarajevo in the two weeks following the cancelled match against Rad (Bjelogrlić 1992c). Bosnian Serbs, Croats 
and Muslims, they and their families had fled to Belgrade, Tuzla and Germany. ${ }^{15}$ It is clear from the shock of many of these players that they had lived and worked in a cohesive urban community. Goran Gutalj, who grew up in Grbavica and was part of Željo's first team when the war began, discussed his feelings after leaving for Belgrade in April 1992:

Until two years ago I didn't know what the word nation meant. I'm a Serb, but nobody asked me about that until yesterday. And how can I forget my childhood, youth, friendships... How can I, today, be on one side, and my friends Mario Stanić [Croat] and Suad Katana [Muslim] on the other? How, when we were always together? (Šećerov 1992a)

By July, the club's presidency were reporting that most of the first team were no longer in Bosnia and Hercegovina, with many having found arrangements with foreign sides (P. T. 1992d). While those who departed faced criticism for abandoning their homeland, the war undoubtedly left many football professionals in uncomfortable situations. Former Željo legend, Ivica Osim, who was Yugoslav national team and Partizan Belgrade coach at the outbreak of war, was exploited by nationalists in both Bosnia and Serbia. In the latter, Sportski žurnal mocked Sarajevo's "[Islamic] fundamentalist" TV HAJAT for calling upon Osim - as well as film director Emir Kusturica and musician Goran Bregović - to quit positions in the Yugoslav capital, with their native Sarajevo under attack (Šećerov 1992b).

But in contrast to these economic migrants, refugees and individuals who were already employed elsewhere, many past and present players remained to rally in defence of both the club and the city. The Željo presidency announced that they were proud of the fact that most of the club's members were on the side of the defenders of the country, with "many on the frontline", while "some have given their lives for freedom" (P. T. 1992c). Edin Sprečo, of the championship winning generation of 1972, became a platoon commander, based on Hrasno Brdo, overlooking Grbavica to the west of Bosnian Serb-held territory. In July 1992 he told an Oslobođenje reporter that he and his colleagues had taken the decision to stand in defence of the country on the day of the abandoned Rad match, following the aforementioned Vrbanja Bridge incident (P. T. 1992b). Of the wartime squad, Željo's captain, Dželaludin Muharemović, joined the special police force at the outbreak of war, while others also enlisted (Wilson 2006, 175-176; Hadžialić 2007, 18). Club supporters were actively engaged in the conflict. For instance, one of the pre-war leaders of the Maniacs, 
Dževad Begić Đilda, has become a legend for Željo fans. A patriotic wartime account, supported by the recollections of longstanding Maniacs, describes how "Sarajevo's greatest fighter" was killed as he tried to recue a civilian who had been shot by a sniper. In 2008, a banner bearing his likeness could be seen on the Grbavica pitch's perimeter fence. Supporters have sung odes to him on the terraces above since the end of the war (Mills 2012, 566-568).

As the conflict progressed, the Football Association of Bosnia and Hercegovina started to plan for a national tournament that would encompass all government-held territory. Difficult wartime conditions resulted in a number of regional competitions, with the best clubs progressing to a final tournament. In chaotic circumstances, the regional stage began in 1993 in some districts, but a Sarajevo competition did not kick-off until June 1994 (Arnautović 2005, 302-304; Hadžialić 2007, 58-59). All of the Sarajevo group matches were played at the Koševo Stadium during a period of supposed ceasefire, though one had to be abandoned when snipers targeted the ground from the surrounding hills (P. T. 1994a). As a former First Federal League club, Željo did not have to qualify via the regional tournament, entering at the semi-final stage instead. Designed to bring together the best teams from the district tournaments and those clubs which had participated at the elite level before the war, the semi-final groups were hosted in four cities: Sarajevo, Zenica, Tuzla and Jablanica ("Počeo nogometni" 1994.). Željo was placed in the Sarajevo group, with all matches taking place at the Koševo Stadium. The team qualified for the eight team final tournament, which was played in the relative safety of Zenica in September 1994 (Hadžialić 2007, 58-59; P. T. 1994c). They performed poorly there, finishing fourth, but their sheer presence was a victory of sorts. Disappointingly for the club's leadership, the opportunity to leave the besieged capital for a short time was exploited by the young squad. Despite the patriotic wartime rhetoric emanating from the organisation, when given the chance to emulate those members of the first team who departed in 1992 many did so. Some opted not to return to Sarajevo, while others secured deals with foreign clubs as a result of their performances. Of the twenty-two players who represented Željo in Zenica, only three were available for selection the following season (Hadžialić 2007, 59).

Like other clubs, Željo's identity became contested. Discussing the evolution of identities in wartime Bosnia and Hercegovina, Maček notes $(2009,126)$ that the new “"nationalist road' cut through not only towns and villages but also 
neighbourhoods, workplaces, friendships, and families." We may also add football clubs to this list. In the aforementioned article about the pride which Željo took in those of its members who were defending the city (P. T. 1992c), members of the wartime presidency also noted that "a negligible group of [the Željo family] ... actively participates on the side of the occupier". Four such individuals were even named, before it was stressed that there "will never again be a place for them beneath Željezničar's roof." While Željo resumed activities in besieged Sarajevo, on the other side of the frontline a rival Serbian Željezničar was formed, with its members laying claim to the legacy of the club founded back in 1921 (Mills 2013b, 964-965). This "other" Željo was based in Vlasenica and participated in the wartime championships of the Bosnian Serb entity. The club was a founder member of the Republika Srpska First League when it commenced in the 1995-96 season (Mills 2013b, 965). From the perspective of many Bosnian Serbs, the territorial situation was such that both Grbavica and the team that called it home belonged to the incipient Serb entity. On that side of the frontline the participation of a Željo in the inaugural Bosnian Championship of 1994 was an object of ridicule:

They know - they know well - that 'Željo' is located on this, our, Serbian side. They know. How can they not know that Željo participated in the Republika Srpska Cup? But they have still, even alongside everything else - usurped the club. Without regard to the fact that the famous Grbavica belongs to Republika Srpska. They are disguising themselves, evidently, in somebody else's clothes. ("Prisvojili" 1994)

Like Bosnia itself, Željo had been torn apart by war.

\section{Return to the Grbavica}

Fortunately for the club that was active on Bosnian Government-held territory - but much to the frustration of the Bosnian Serb administration - the November 1995 Dayton Peace Accords, which ended the war, did not allow for a permanent partition of the new country's capital. The final "cartographic fix" (Toal and Dahlman 2011, 149) was based upon a federal Bosnia and Hercegovina, divided between the Republika Srpska [Serbian Republic] and the Muslim-Croat Federacija [Federation]. However, when discussing the fate of Sarajevo the leader of the peace initiative, Richard Holbrooke, is alleged to have stated that "we shall not create another Berlin Wall at the end of the twentieth century" (Silber and Little 1996, 371). Nevertheless, the consequences of such a territorial division had already been contemplated by the republic's sports journalists. In the context of the short-lived Owen-Stoltenberg Plan 
of 1993, which envisaged a Bosnian Union with three constituent ethnic republics (See Toal and Dahlman 2011, 153), Triumph ran a satirical piece on what the plan might mean for football ("Sport briše" 1994). In it, David Owen and Thorvald Stoltenberg discuss a situation which must have been inspired by the wartime plight of Željo and the Grbavica Stadium:

OWEN: What are you saying? They are complaining because the border goes across the centre of a football pitch?!

STOLTENBERG: Yes. They called me from the Sports Association. What shall I say to them?

OWEN: Tell them to create two pitches and two stadiums from one. And two teams. That is good for mass participation [masovnost].

STOLTENBERG: What will they do about the ball when it is kicked into the other part of the Union?

OWEN: Let them take good care when shooting, so that a border incident isn't created because of it.

As has been demonstrated, when it came to Željo there would be nothing satirical about the idea of forming two teams out of one. But the stadium was spared this plight.

The allocation of Grbavica to the city of Sarajevo and the Federation offered Željo's administrators and players the concrete prospect of a return. In December 1995 head coach Mišo Smajlović conjured an image of his club's future:

There will be full terraces again, blue flags will fly once more, our name will hover on the lips of thousands of people. Do you know what that means? Well, it will be pandemonium! ... people will live for football once again, and from football. (Kreho 1995)

The genuine prospect of a return to some kind of normality enabled Smajlović to dream of a stable home, with facilities for training. Unlike their on-going tenancy at Koševo, the rent would not be prohibitive. Moreover, a strong sense of topophilia and belonging is evident in the words of those who yearned for the highly symbolic Grbavica Stadium during the war (Bale 1993, 70-73). Of course, much would need to be done to reclaim the stadium before any of these aspirations could be fulfilled: "I heard that the old wooden stand was destroyed by fire, but that doesn't matter: a new, even more beautiful one will be built ... I can't wait for the day of our return." (Kreho 1995)

The implementation of Dayton brought about the reintegration of the Grbavica suburb in March 1996. However, there was a high price. Tens of thousands of Serb 
residents, most of whom had always lived in Sarajevo - and many of these had supported the multiethnic Željo before the war - fled suburbs like Grbavica as Bosnian Serb forces departed. Many in this community feared for their safety and did not wish to live in a polity which they perceived to be dominated by Muslims (Armakolas 2007, 86-88; Sell 2000, 179; Judah 2000, 215). Others were forcibly evicted by those members of their own ethnonational group who favoured separation (Toal and Dahlman 2011, 166). Vacant apartments were quickly filled by Bosniaks who had been cleansed from their homes in eastern Bosnia. As a result of such processes Bosniaks accounted for 87\% of the city's population by 1997 (Stefansson 2007, 59).

According to Louis Sell (2000, 180), the "emptying" of suburbs that had been under Serb control "locked into place the last piece of a jigsaw puzzle that completed the new ethnic map of Bosnia." Stef Jansen $(2013,32)$ explains that following reintegration Grbavica gradually fell "in the horizon of bodily movement of most Sarajevans" once again, despite its troubling wartime associations [Fig. 9]. By contrast, Dayton turned the suburb into "an affective no-go area" for a portion of those Serbs who found themselves living on the other side of the Inter-Entity Boundary Line.

Figure 9 here

As a result, while the football club regained its premises it was never fully able to return to its previous status as a club for all ethnic groups, despite concerted efforts. While some Serbs and Croats continue to support Željo, a post-war ethnographic study of the club's supporters' group (Özkan 2013) described it as “predominantly Bosnian Muslim", though stressing that Željo fans were more inclined to promote the notion of inclusive national identity than their city rivals (Özkan 2013, 4 and 26). This latter desire has provoked rival supporters - including those from Bosniak majority cities - to mock Željo as a Muslim club (Sterchele 2013, 984). By contrast, members of Bosnia's other constituent nations have featured among the club's footballers and coaching staff, as the professional game has become increasingly mixed since the war (Sterchele 2013, 978-979). With the return of Željo to the Grbavica, the claims of its rival Serbian incarnation were heavily dented. Željezničar Srpsko Sarajevo were relegated from the Republika Srpska First League in 1998 and, while the team began to participate in the Second League, it did not complete the 1998-99 season (Mills 
2013b, 964-965). According to a historian of the surviving Željo (Hadžialić 2007, 18), the "artificial creation" on the other side of the Inter-Entity Boundary Line "vanished in the rubbish dump of history after a few years."

Željo supporters were heavily involved in the post-war rehabilitation of Grbavica, removing concrete, bushes and trees from the pitch. Željko remembers (Interview 2008) that the first match after the war was held "almost immediately - as soon as we cleared out all the damage, the dirt and the threats within the stadium ... after the reintegration of the Grbavica settlement itself".

Figure 10 here

Amidst the destruction of the post-war suburb [Fig. 10], Željo proudly walked onto the pitch of their shattered ground and played their first match on 2 May, 1996. Twenty thousand people watched an historic encounter against rivals Sarajevo (Kajan 1999, 164-165). Much to the delight of the crowd, Bosnian president Alija Izetbegović performed a ceremonial kick-off, alongside club legend turned patriotic military defender, Edin Sprečo (Kajan 2007, 214).

Since the war Grbavica Stadium has been gradually rebuilt. The grand old Main Stand has been replaced with a modest new structure, while the mangled roof of the 1980s North Stand has been repaired. New seats now hide the war-weary concrete of its terraces. Yet, this has been a slow process. The floodlights were not restored until 2009 ("Na današnji dan” 2013). With Grbavica as its home, Željo has competed at the highest levels in post-war Bosnia and Hercegovina. The process of football integration was also a slow one. Bosnian Croat teams from Western Hercegovina only joined the national championship in 1997, with their Serbian counterparts following suit in 2002 (Cooley and Mujanović 2014, 43 and 53). In these narrow circles Željo enjoyed significant success, winning league and cup doubles in 2001, 2002 and 2013, alongside numerous other victories. These were added to the club's solitary - but more hard-fought - Yugoslav title of 1972 (Hadžialić 2007, 77-83 and 122-125). The team has also represented independent Bosnia in European competitions, though putting up little resistance and never replicating the great UEFA Cup run of 1985. Since the war, Željo has not had the resources to compete beyond Bosnia's borders, while talented young players are swiftly snapped up by foreign clubs.

The way in which Željo's part in the conflict is remembered has had a direct impact on the post-war collective identity of the club's supporters [Fig. 11]. Once 
again, Maček's approach is instructive here. She emphasises that wartime national identities in the city "were emergent rather than preexisting" $(2009,124)$. For her, the conflict was "the constitutive element of ethnonational groups":

War enforced both division and homogenization along ethnonational lines, and thus created antagonistic groups, contrary to a widespread misconception that the war was caused by nationalist antagonisms. $(2009,208)$

In 2008, the Maniacs erected a plaque at the rear of the West Stand in memory of those Željo supporters who gave their lives while defending "their city and their country from the Serbo-Montenegrin Aggressor" (Mills 2012, 563-564). Despite continuing efforts by the Maniacs to promote themselves as an inclusive group, this ethnicised description portrays a more exclusive collective identity for the post-war club and its supporters.

Figure 11 here

Ethnically specific language has also been deployed on the websites of supporters' groups, albeit in a fashion that discriminates only against Serbs of a particular political persuasion. For instance, founder members of the Joint Union subgroup are keen to stress that only Serb extremists are prohibited from membership:

... this group accepts only Bosniaks, Croats and Serbs who did not follow the failed Četnik ideology of creating a Greater Serbia. We have witnessed that some ultra-nationalists have separated and turned their backs on Željo, this city and our country. However, despite all of this, we have remained a multi-ethnic supporters' group. ("Joint Union" 2015)

When addressing specific members of the group who opted to fight on the other side of the frontline, the Joint Union website is - perhaps understandably - more aggressive in its treatment:

How was it to shoot at your own city in which you were born[?] ... IT MUST BE DISGUSTING ... Read these pages and watch ... on television, YOU HAVE CHOSEN YOUR SIDE YOURSELF. ("Joint Union” 2015)

The pain of wartime divisions has undoubtedly been compounded by the ethnic "unmixing" embodied by both the conflict and Dayton. 


\section{Conclusion}

The 1996 match against city rivals FK Sarajevo signalled an end to Željezničar's war. Whilst their Grbavica Stadium felt the full force of the siege, other Bosnian stadiums witnessed scenes of a far more horrific nature. For instance, lower league grounds were harnessed as detention facilities and execution sites during the Srebrenica massacre of 1995 (Mills 2013b, 966; Honig and Both 1997, 59-60). Nevertheless, this micro-historical approach to the plight of Grbavica Stadium underlines the extent to which commonplace activities and the lives of ordinary people were affected by conflict. The complexities of Bosnian society were, and are, reflected in institutions and clubs such as Željo. As a result they provide an alternative vantage point from which to examine the evolution of the city of Sarajevo and the wider state-building projects that encompassed it. At a local level, the organisation offers a means of visualising the development of the Grbavica suburb, from its socialist foundations to its post-Dayton reintegration. In this way, the life of the football ground and those who frequent it map onto the history of the Socialist Federal Republic of Yugoslavia, its dissolution and the independent Bosnia and Hercegovina that emerged in its wake. The partition of the stadium, the club and its supporters' group - as well as tenacious efforts to stifle the latter - were representative of political developments in those parts of the state where the ethnic balance was reengineered during and after the conflict.

More broadly, the frontline plight of Grbavica offers an alternative wartime experience for a football stadium compared to the aforementioned examples, studied in the context of earlier wars. At the time of writing the stadium of Shakhtar Donetsk in eastern Ukraine, built for the European Championships of 2012, has also been abandoned and damaged in the face of fierce fighting (Burridge 2015). Perhaps like the Donetsk ground today, even when part of the frontline the Grbavica Stadium continued to serve as a highly symbolic site for those players, supporters, politicians, workers and citizens who felt an emotional attachment - a sense of topophilia towards it. While the siege undoubtedly affected the bond between Željo supporters and "their" stadium (Lanfranchi and Taylor 1995, 194), the prospect of a return for those in government-held territory stood as an alluring vision of post-war peace. For those Bosnian Serbs on the other side of the frontline, the post-war settlement that placed Grbavica out of reach triggered an abandonment of claims to the heritage of Željezničar Football Club, compounding their displacement from pre-war homes. Like the ethnonational identities that emerged during the course of the war, emotional 
attachments to Željo and the Grbavica were irreparably transformed by four years of fierce fighting. While the physical space has since been reclaimed, the emotional scars linger on like the shell holes on the tired concrete terraces [Fig. 12].

Figure 12 here

\footnotetext{
${ }^{1}$ Slavija had been a club for the city's Serbs (Mills 2013a, 52).

${ }^{2}$ These figures are somewhat complicated by the $15.9 \%$ who declared a Yugoslav national identity.

${ }^{3}$ For more on the proximity of the Police Academy to Grbavica Stadium see: 2001-2003. Case IT-9829-T. Stanislav Galić - Interview Transcripts, International Criminal Tribunal for the former Yugoslavia. http://icr.icty.org/. 2780-2781.

${ }^{4}$ The Yugoslav People's Army assisted many with flights out of the city during this turbulent period (Maček 2009, 90).

${ }^{5}$ Borac Banja Luka continued to participate in the Yugoslav league system. Although Banja Luka was located in Bosnian Serb-held territory for the duration of the war, the club relocated to Serbia to fulfil its home fixtures.

${ }^{6}$ 2001-2003. Case IT-98-29-T. Stanislav Galić - Interview Transcripts, International Criminal Tribunal for the former Yugoslavia. http://icr.icty.org/. 2026.

${ }^{7}$ Twelve minutes of this footage is available online ("Na današnji dan" 2013).

${ }^{8}$ 2001-2003. Case IT-98-29-T. Stanislav Galić - Interview Transcripts, International Criminal Tribunal for the former Yugoslavia. http://icr.icty.org/. 2028.

${ }^{9}$ 2001-2003. Case IT-98-29-T. Stanislav Galić - Interview Transcripts, International Criminal Tribunal for the former Yugoslavia. http://icr.icty.org/. 2752.

10 2004-2009. Case IT-98-29/1. Dragomir Milošević - Interview Transcripts, International Criminal Tribunal for the former Yugoslavia. http://icr.icty.org/. 4742.

11 2004-2009. Case IT-98-29/1. Dragomir Milošević - Interview Transcripts, International Criminal Tribunal for the former Yugoslavia. http://icr.icty.org/ 2931; Interview 2008. Derry City's Brandywell Stadium was also utilised by a sniper in 1971 (Cronin 2000, 70).

12 2001-2003. Case IT-98-29-T. Stanislav Galić - Interview Transcripts, International Criminal Tribunal for the former Yugoslavia. http://icr.icty.org/. 2816.

13 2001-2003. Case IT-98-29-T. Stanislav Galić - Interview Transcripts, International Criminal Tribunal for the former Yugoslavia. http://icr.icty.org/. 2892-2894 and 2900-2901.

14 2001-2003. Case IT-98-29-T. Stanislav Galić - Interview Transcripts, International Criminal Tribunal for the former Yugoslavia. http://icr.icty.org/. 2892-2894 \& 2900-2901. For more on Sarajevo's Serbs and enforced trench digging see Judah $(2000,217)$.

${ }^{15}$ The nine discussed were: Fadil Hodžić, Rade Bogdanović, Goran Gutalj, Simo Krunić, Siniša Nikolić, Jasminko Velić, Mario Stanić, Vito Milošević and Milan Pavlović.
}

\section{Acknowledgements}

I would like to thank Željko, Hamo and Lejla of the Maniacs supporters' group. I am also grateful to Cathie Carmichael, Ivana Maček and the anonymous reviewers for their valuable comments on an earlier draft.

\section{References}

Interview

2008. The Maniacs of FK Željezničar - Željko, Hamo \& Lejla. Group interview conducted by author. Sarajevo. May. Željko has been attending Željezničar matches home and away since the 1970s. He has been a member of the Maniacs since it was founded in 1987. Hamo has watched Željo since the early 1980s. He has been a 
member of Joint Union since his high school days. Lejla is a supporter who lived in Grbavica, in close proximity to the stadium, during the siege.

International Criminal Tribunal for the former Yugoslavia

2001-2003. Case IT-98-29-T. Stanislav Galić - Interview Transcripts, International Criminal Tribunal for the former Yugoslavia. http://icr.icty.org/.

2004-2009. Case IT-98-29/1. Dragomir Milošević - Interview Transcripts, International Criminal Tribunal for the former Yugoslavia. http://icr.icty.org/.

1991. "Transkript govora Radovana Karadžića u BH parlamentu", October 15. Exhibit P69.A. 2000-2009. Case IT-00-39. Momčilo Krajišnik, International Criminal Tribunal for the former Yugoslavia. http://icr.icty.org/. 1-4

Contemporary Newspaper and Magazine Articles

Bjelogrlić, M. 1992a. "Fudbal ostao na barikadi." Sportski žurnal, Belgrade, 27 March.

Bjelogrlić, M. 1992b. "Barikade oko Grbavice.” Sportski žurnal, Belgrade, 6 April.

Bjelogrlić, M. 1992c. “"Željo’ bez tima”, Sportski žurnal, Belgrade, 19 April.

Bjelogrlić, M. 1992d. "Granate i na Grbavici.” Sportski žurnal, Belgrade, 23 April.

1991. "Iz navijačkog albuma.” Tempo, Belgrade, 5 June.

1992. “Josip Katalinski direktor SD ‘Željezničar',” Oslobođenje, Sarajevo, 14 July.

Kreho, I. 1995. "Grbavica, ponovo, sjajna lica." Champion, Sarajevo, 15 December.

Lučić, Maristela. 1992. "War Erupts in Sarajevo - Bosnian Lebanon." Politika: The International Weekly, Belgrade, 11 April.

M. A. 1992. "Ubi ih neizvesnost.” Sportski žurnal, Belgrade, 8 April.

M. B. 1991. “Juga' na Grbavici.” Tempo, Belgrade, 16 October.

1991. "'Manijaci' protiv 'Guzonja'.” Cao Tifo, Belgrade, June.

P. T. 1992a. "Željezničaru i Bosni po dva miliona dinara." Oslobođenje, Sarajevo, 13 July.

P. T. 1992b. "Vrebao je Šešelj." Oslobođenje, Sarajevo, 13 July.

P. T. 1992c. "Ponose se svojim borcima." Oslobođenje, Sarajevo, 14 July.

P. T. 1992d. "Uskoro i gradski derbi." Oslobođenje, Sarajevo, 29 July.

P. T. 1994a. "Mečevi 'začinjeni’ snajperima." Oslobođenje, Sarajevo, 17 June.

P. T. 1994b. "Bogatstvo u opremi." Oslobođenje, Sarajevo, 7 July.

P. T. 1994c. "Sarajevo, ili...." Oslobođenje, Sarajevo, 6 September.

Pašalić, A. 1992. "Na dresu piše - borac." Oslobođenje, Sarajevo, 13 July.

1994. "Počeo nogometni šampionat Bosne i Hercegovine" Oslobođenje, Sarajevo, 16 July.

1994. "Prisvojili 'Želju'.” Derbi, Banja Luka, 13 September.

Šećerov, Zoran. 1992a. "Miris dunja i baruta." Sportski žurnal, Belgrade, 13 April.

Šećerov, Zoran. 1992b. "Drviš i smrt, drugi čin.” Sportski žurnal, Belgrade, 22 April.

Simeunović, Miodrag. 1991. "Yugoslavia Resides in Bosnia - Sport Ambassador of

Peace Again." Politika: The International Weekly, Belgrade, 19 October.

Simeunović, Miodrag. 1992. "From Friday to Friday - War Strikes at Sports."

Politika: The International Weekly, Belgrade, 11 April.

1952. "SD Željezničar.” Sport, Belgrade, 30 August.

1994. "Sport briše granice." Triumph, Sarajevo. 
Secondary Literature

Anđelić, Dragoljub, ed. 1982. Fudbalski Klub Željezničar, 1921-1981. Sarajevo: FK Željezničar Sarajevo.

Ankant. 2008. "Ledra Palace and Old Stadium of Cetinkaya." Flickr.com www.flickr.com/photos/ankant/2407977920/in/photostream/. 31 March.

Arich-Gerz, Bruno. 2010. "Killing Sports Fields: The Amahoro Stadium Complex in Kigali, Rwanda." In: Stadium Worlds: Football, Space and the Built Environment, edited by Sybille Frank and Silke Steets, 114-126. London: Routledge.

Armakolas, Ioannis. 2007. "Sarajevo No More? Identity and the Sense of Place among Bosnian Serb Sarajevans in Republika Srpska." In: The New Bosnian Mosaic: Identities, Memories and Moral Claims in a Post-War Society, edited by Xavier Bougarel, Elissa Helms and Ger Duijzings, 79-99.

Arnautović, Demir. 2005. Zlatna knjiga fudbala. Tuzla: Narodna i univerzitetska biblioteka "Derviš Sušić".

Bale, John. 1993. Sport, Space and the City. London: Routledge.

Brentin, Dario, Armina Galijaš, and Hrvoje Paić, eds. 2014. Special Issue: Football and Society, Südosteuropa, 62 (2).

Burridge, Tom. 2015. "Look Inside Donetsk's Now-Empty Football Stadium.” BBC News, April 5, http://www.bbc.co.uk/news/world-europe-32187880.

Cooley, Laurence, and Jasmin Mujanović. 2014. "Changing the Rules of the Game: Comparing FIFA/UEFA and EU Attempts to Promote Reform of PowerSharing Institutions in Bosnia-Herzegovina." Global Society 29 (1): 42-63.

Cronin, Mike. 2000. "Playing Away from Home: Identity in Northern Ireland and the Experience of Derry City Football Club.” National Identities 2 (1): 65-79.

Donia, Robert. J. 2009. Sarajevo: A Biography. London: Hurst.

Draškić, Miladin. 1988. "Željezničari grade stadion 'Grbavicu'." In: Sarajevo u sociajalističkoj Jugoslaviji, edited by Miodrag Čanković, Vo1. I, 591-594. Sarajevo: Istorijski arhiv Sarajevo.

Duke, Vic, and Liz Crolley. 1996. Football, Nationality and the State. Harlow: Longman.

Eriksen, Thomas Hylland. 2001. Small Places, Large Issues: An Introduction to Social and Cultural Anthropology. London: Pluto.

Gjelten, Tom. 1996. Sarajevo Daily: A City and Its Newspaper Under Siege. New York: Harper Perennial.

Ginzburg, Carlo. 1993. "Microhistory: Two or Three Things That I Know about It", Critical Inquiry, 20 (1): 10-35.

Glenny, Misha. 1996. The Fall of Yugoslavia: The Third Balkan War. London: Penguin.

Hadžialić, Nedžad. 2007. Fudbalski Klub Željezničar 1982.-2007. Sarajevo: Nedžad Hadžialić.

Honig, Jan Willem and Norbert Both. 1997. Srebrenica: Record of a War Crime. London: Penguin.

Hughson, John, and Fiona Skillen, eds. 2014. Football in Southeastern Europe: From Ethnic Homogenization to Reconciliation. London: Routledge

2015. "Joint Union." The Maniacs Official Website. www.themaniacs.org/tm/joint-union. Accessed July 2015.

Jansen, Stef. 2013. "People and things in the ethnography of borders: materialising the division of Sarajevo", Social Anthropology/Anthropologie Sociale, 21 (1): 23-37. 
Joyner, Charles. 1999. Shared Traditions: Southern History and Folk Culture.

Champaign: University of Illinois Press.

Judah, Tim. 2000. The Serbs: History, Myth and the Destruction of Yugoslavia. New Haven and London: Yale Nota Bene.

Kajan, Dževad. 1999. Sarajevski derbi: 74 prvenstvene utakmice, 1954-1999. Sarajevo: Mediapress.

Kajan, Dževad. 2007. Bilo jednom na Grbavici. Sarajevo: Megamedic.

Lampe, John R. 2003. Yugoslavia as History: Twice There was a Country. Cambridge: Cambridge University Press.

Lanfranchi, Pierre, and Matthew Taylor. 1995. "Professional Football in World War Two Britain." In: War Culture: Social Change and Changing Experience in World War Two Britain, edited by Pat Kirkham and David Thoms, 187-197. London: Lawrence and Wishart.

Lanfranchi, Pierre, and Matthew Taylor. 2001. Moving with the Ball: The Migration of Professional Footballers. Oxford: Berg.

Luedtke, Brandon. 2012. "Playing Fields and Battlefields: The Football Pitch, England and the First World War." Britain and the World 5 (1): 96-115.

Maček, Ivana. 2009. Sarajevo Under Siege: Anthropology in Wartime. Philadelphia: PENN.

Malcolm, Noel. 2002. Bosnia: A Short History. London: Pan Macmillan.

Mason, Tony, and Eliza Riedi. 2010. Sport and the Military: The British Armed Forces, 1880-1960. Cambridge: Cambridge University Press.

Mills, Richard. 2010. "Velež Mostar Football Club and the Demise of 'Brotherhood and Unity' in Yugoslavia, 1922-2009," Europe-Asia Studies 62 (7): 1107-1133.

Mills, Richard. 2012. "Commemorating a Disputed Past: Football Club and Supporters' Group War Memorials in the Former Yugoslavia." History, 97 (328): 540-577

Mills, Richard. 2013a. "Domestic Football and Nationalism in the Construction and Destruction of Socialist Yugoslavia, 1945-1995.” PhD diss., University of East Anglia.

Mills, Richard. 2013b. "Fighters, Footballers and Nation Builders: Wartime Football in the Serb-held Territories of the Former Yugoslavia, 1991-1996." Sport in Society 16 (8): 945-972.

Morrison, Kenneth. 2013. "Sarajevo's Holiday Inn: Eventful Past of Historic Hotel." BBC News, November 2, http://www.bbc.co.uk/news/world-europe-24730400.

2013. "Na današnji dan otvoren Željin dom - stadion Grbavica.” Radio Sarajevo. September 12. http://www.radiosarajevo.ba/novost/125146/na-danasnji-danotvoren-zeljin-dom-stadion-grbavica

Özkan, Özgür Dirim. 2013. "Football Fandom and Formation of Cultural Differences in Bosnia: A Comparative Ethnographic Study on FK Željezničar and FK Sarajevo Fans in Sarajevo", Working Paper: Kick It! The Anthropology of European Football, Football Research in an Enlarged Europe Conference, University of Vienna, October, http://www.free-project.eu/documentsfree/Working\%20Papers/Football\%20Fandom\%20Formation $\% 20 \mathrm{Cultural} \% 20$ Differences\%20Bosnia\%20Comparative\%20Ethnographic\%20Study\%20Zeljez nicar\%20Sarajevo\%20(OD\%20Ozkan).pdf

Özkan, Özgür Dirim. 2014. "Perception of Bosnia and Herzegovina's Qualification to FIFA World Cup 2014 by Different Ethnic Groups", Sport Mont Journal 12 (40, 41, 42): 167-174. 
Read, Peter, and Marivic Wyndham, 2008. "Putting Site Back into Trauma Studies: A Study of Five Detention and Torture Centres in Santiago, Chile." Life Writing 5 (1), 79-96.

Sell, Louis. 2000. "The Serb Flight from Sarajevo: Dayton's First Failure." East European Politics and Societies 14 (1): 179-202.

Silber, Laura, and Allan Little, 1996. The Death of Yugoslavia. London: Penguin.

Sterchele, David. 2013. "Fertile Land or Mined Field? Peace-Building and Ethnic Tensions in Post-war Bosnian Football." Sport in Society 16 (8): 973-992.

Stefansson, Anders. 2007. "Urban Exile: Locals, Newcomers and the Cultural Transformation of Sarajevo." In: The New Bosnian Mosaic: Identities, Memories and Moral Claims in a Post-War Society, edited by Xavier Bougarel, Elissa Helms and Ger Duijzings, 59-77.

Toal, Gerard, and Carl T. Dahlman, 2011. Bosnia Remade: Ethnic Cleansing and Its Reversal. Oxford: Oxford University Press.

Wilson, Jonathan. 2006. Behind the Curtain: Travels in Eastern European Football. London: Orion.

Zec, Dejan, and Miloš Paunović, 2014. "Football's Positive Influence on Integration in Diverse Societies: The Case Study of Yugoslavia." Soccer and Society 16 (23) $232-244$. 